\title{
The role of antioxidant micronutrients in the rate of recovery of burn patients: a systematic review
}

\author{
Mary Adjepong ${ }^{1}$, Pius Agbenorku², Patricia Brown ${ }^{1}$ and Ibok Oduro ${ }^{1}$
}

\begin{abstract}
Burn injury can be detrimental to the health of individuals, meanwhile victims lose proteins and micronutrients in wound exudates. Victims also experience extensive protein catabolism. These make them prone to malnutrition. Burn patients also suffer a lot of emotional trauma that reduce nutrient intake. The aim of this paper was to review primary evidence on the effect of antioxidant micronutrients on the recovery rate of burn patients. Electronic databases such as PubMed, BioMed, and Cochrane were systematically searched between January 1, 2014, and January 30, 2014. Keywords include vitamin A, vitamin C, vitamin E, ascorbic acid, zinc, copper, selenium, tocopherol, carotenoids, dietary intake, supplementation, wound healing, infection, recovery rate, and burn patients. The systematic search was done to retrieve all published data from 1990 to 2013. A total of 518 journal articles were obtained, and after the removal of duplicates, reviews, commentaries, and studies with non-human subjects, 11 papers were accepted for review. The review considered only papers that were published, and there might be some unpublished data that may have been omitted. Generally, the wound healing time and infection rates were reduced by the administration of the antioxidant micronutrients. The review revealed that there was no such published work in developing countries and children were excluded from most studies. It was also stated clearly that there was no uniformity in burn management; hence, there is a need for more studies on burn management in various populations.
\end{abstract}

Keywords: Burn, Micronutrients, Recovery, Infection, Tocopherol, Carotenoids, Ascorbic acid

\section{Background}

Burn injury, which is the most devastating of all injury and a serious global public health crisis, is defined as an injury to the skin or other organic tissues primarily caused by heat or due to radiation, electric current, friction, or exposure to chemicals [1]. It is therefore classified under three main headings depending on the cause of injury: chemical burns are caused by exposure to acids or alkali; thermal burns are caused by hot water, hot oil, and open flame; and electrical burns are caused as a result of exposure to high voltage current or lightning. It can be fatal because it can lead to infection and death in some of its victims. It has been reported by World Health Organization that 265,000 people die

\footnotetext{
* Correspondence: pimagben@yahoo.com

${ }^{2}$ Department of Surgery, Reconstructive Plastic Surgery \& Burns Unit, Komfo

Anokye Teaching Hospital, School of Medical Sciences, College of Health

Sciences, Kwame Nkrumah University of Science and Technology, Kumasi,

Ghana

Full list of author information is available at the end of the article
}

globally from open fires alone and there are more deaths caused by scalds and electrical burns [1].

Infection, delayed wound healing, and extensive protein catabolism are among the main causes of mortality in burns. There is also a compromised immune system in burn patients. The main cause of immune suppression in burn patients is the presence of reactive oxygen species leading to delayed wound healing, and this increases the patient's susceptibility to infection [2].

Medical nutrition therapy (MNT) remains pivotal in the management of burn injury. The goal of MNT is to maintain body mass, prevent starvation and specific nutrient deficiencies, improve wound healing, manage infection, and restore protein losses [3]. These goals are met through adequate portions of macronutrients and micronutrients.

Numerous studies have been done to examine the efficacy of different micronutrients on thermally injured patients [4]. Several reviews and commentaries as well as 
journal publications exist, but it is important to note that despite the numerous studies and journal publications in this area, little published data exist for antioxidant micronutrients and there are no published work found for Africa. Various electronic databases such as PubMed, BioMed, and Cochrane Library were searched using appropriate keywords. Some of the keywords include recovery rate of burn patients, micronutrient and burn patients, dietary intake, supplementation, vitamin $\mathrm{A}$, vitamin $\mathrm{C}$, vitamin $\mathrm{E}$, ascorbic acid, tocopherol, carotenoids, copper, zinc, infection, sepsis, wound healing, protein catabolism, and protein turnover. All published data relevant to the scope of the study were included in the review.

The hypothesis of this review was that intake of antioxidant micronturients or its administration in burn patients improves recovery outcomes. The exposure measures were the intake of antioxidant micronutrients, and the main outcome measures were wound healing and infection.

\section{Review}

\section{Search strategy}

A systematic search was done, and all published data from 1990 to 2013 on the effects of various antioxidant micronutrients on the recovery rate of burn patients of all ages were retrieved. Papers with patients having varying degrees of burns suffered were included as well as papers with patients of both sexes.

The main search engines used include PubMed, BioMed, and Cochrane Library. The searches were conducted systematically to find the effect of each of the micronutrients on the various outcomes: wound healing time, infection rate, length of hospital stay, protein turnover, and catabolism.

Exposures for this review are vitamin A, vitamin E, vitamin $C$, zinc, copper, and selenium, while the main outcome was recovery rate, wound healing time, protein turnover, sepsis, infection, mortality rate and protein catabolism. The category of subjects included all age groups. Though most of the studies had age restriction, there were no exclusions to the ages of the patients in the search. The only works that were excluded were those that were done with non-human subjects.

Systematic literature searching and selection are presented in Fig. 1.

\section{Inclusion and exclusion criteria}

Below were the inclusion criteria:

- Population: human population of all ages.

- Study designs: experimental and observational studies.

- Outcomes: outcomes measured include rate of recovery, length of hospital stay, infection, sepsis, wound healing time, protein turnover, protein catabolism, and mortality rate.

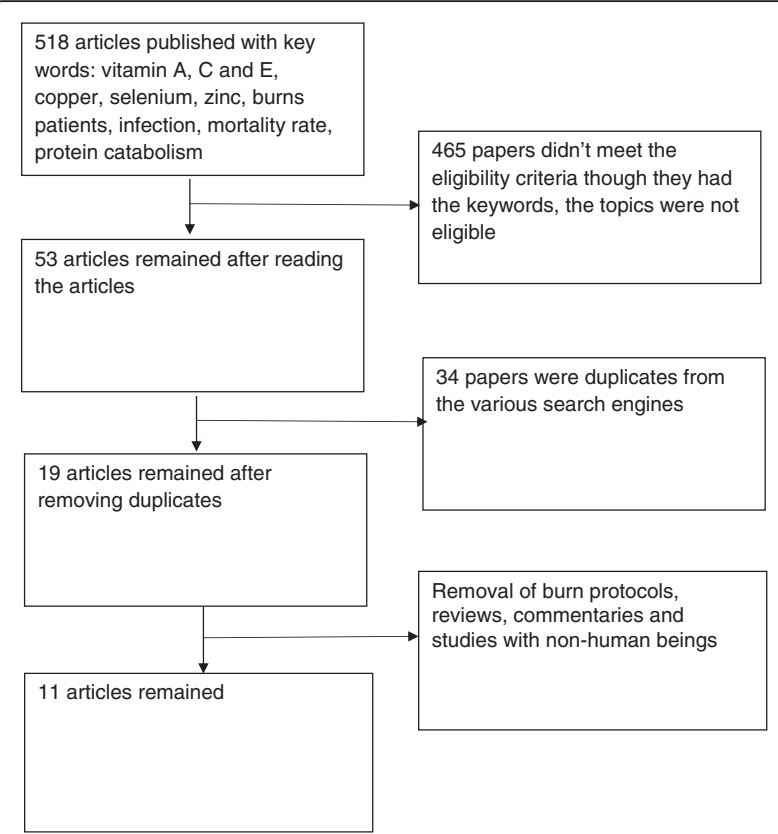

Fig. 1 Literature searching and selection

The following search results were excluded:

- Reviews.

- Reports on various protocols used for managing burn patients were excluded.

- Studies that were done with non-human subjects.

- Various case studies that did not meet the inclusion criteria.

\section{Search results}

A total number of 518 journal articles were obtained from the various search engines. When the repeated articles were removed, articles that did not meet the criteria such as reviews and burn protocols were also excluded. At the end of the systematic search, only 11 remained.

\section{The findings on the studies involving effect of antioxidant micronutrient on the rate of recovery}

Based on the results obtained from the various searches, a summary of the results were done and presented in Table 1.

\section{Study designs}

The prevailing study designs used in the various studies were clinical trials where the micronutrients were administered to the patients intravenously, orally, or through enteral feeding and various outcomes were measured after the intervention. 
Table 1 Summary of the main findings of the research

\begin{tabular}{|c|c|c|c|c|c|c|c|}
\hline $\begin{array}{l}\text { Author and } \\
\text { country }\end{array}$ & Study designs & Aim of the study & $\begin{array}{l}\text { Micronutrients involved and } \\
\text { concentrations }\end{array}$ & $\begin{array}{l}\text { Severity of burns } \\
\text { (TBSA) }\end{array}$ & Age of patients & Outcomes & Gaps \\
\hline $\begin{array}{l}\text { Berger et al., } \\
\text { Switzerland [6] }\end{array}$ & $\begin{array}{l}\text { Randomized } \\
\text { controlled trials } \\
\text { (clinical trials) } \\
(n=21)\end{array}$ & $\begin{array}{l}\text { To investigate the effect of } \\
\text { large intravenous doses of } \\
\text { trace element supplements } \\
\text { on circulatory, antioxidant } \\
\text { status, and the clinical } \\
\text { outcomes after major burns }\end{array}$ & $\begin{array}{l}\text { a) Copper ( } 3.75 \mathrm{mg} \text { in IV and } \\
2.7 \mathrm{mg} \text { in feeds) } \\
\text { b) Zinc ( } 37.5 \mathrm{mg} \text { in IV and } \\
21.5 \mathrm{mg} \text { in feeds) } \\
\text { c) Selenium ( } 375 \mu \mathrm{gg} \text { in IV and } \\
90 \mathrm{mg} \text { in feeds) }\end{array}$ & $\begin{array}{l}\text { Greater or equal } \\
\text { to } 10 \% \text { : greater } \\
\text { than } 20 \%\end{array}$ & 16 to 65 years & $\begin{array}{l}\text { - Higher circulation } \\
\text { of plasma and skin } \\
\text { tissue contents of } \\
\text { selenium and zinc } \\
\text { - Decreased } \\
\text { pulmonary } \\
\text { infection } \\
\text { - Better wound } \\
\text { healing }\end{array}$ & $\begin{array}{l}\text { - Multicenter studies should be } \\
\text { done }\end{array}$ \\
\hline $\begin{array}{l}\text { Berger et al., } \\
\text { Switzerland [5] }\end{array}$ & $\begin{array}{l}\text { Randomized } \\
\text { controlled trials } \\
\text { (clinical trials) } \\
(n=21)\end{array}$ & $\begin{array}{l}\text { To assess the effects of trace } \\
\text { element supplements on } \\
\text { systemic substrate turnover } \\
\text { and local protein metabolism } \\
\text { during wound healing after } \\
\text { major burns }\end{array}$ & $\begin{array}{l}\text { a) Copper }(59 \mu \mathrm{mol}) \\
\text { b) Selenium }(4.8 \mu \mathrm{mol}) \\
\text { c) Zinc }(574 \mu \mathrm{mol})\end{array}$ & $\begin{array}{l}\text { Greater or equal } \\
\text { to } 10 \% \text { : greater } \\
\text { than } 20 \%\end{array}$ & 16 to 65 years & $\begin{array}{l}\text { - Increase skin tissue } \\
\text { concentration of } \\
\text { selenium and zinc } \\
\text { - Decrease protein } \\
\text { catabolism }\end{array}$ & $\begin{array}{l}\text { - Multicenter studies should be } \\
\text { done }\end{array}$ \\
\hline $\begin{array}{l}\text { Berger et al., } \\
\text { Switzerland [4] }\end{array}$ & $\begin{array}{l}\text { Randomized } \\
\text { controlled trials } \\
\text { (clinical trials) } \\
(n=41)\end{array}$ & $\begin{array}{l}\text { To determine the effect of } \\
\text { trace element } \\
\text { supplementation on } \\
\text { nosocomial or intensive care } \\
\text { unit-acquired pneumonia }\end{array}$ & $\begin{array}{l}\text { a) Copper ( } 2.5 \text { to } 3.1 \mathrm{mg} / \text { day) } \\
\text { b) Zinc ( } 26.2 \text { to } 31.4 \mathrm{mg} / \text { day) } \\
\text { c) Selenium ( } 315 \text { to } 380 \mu \mathrm{gg} / \\
\text { day) }\end{array}$ & Greater than $20 \%$ & 16 to 65 years & $\begin{array}{l}\text { - Reduced } \\
\text { pulmonary } \\
\text { infections } \\
\text { - Normalized plasma } \\
\text { GSHPx activity, } \\
\text { increased tissue } \\
\text { selenium and zinc } \\
\text { concentrations } \\
\text { - An improved } \\
\text { wound healing } \\
\text { - A reduction in } \\
\text { length of stay }\end{array}$ & $\begin{array}{l}\text { - Dose response study should } \\
\text { be done }\end{array}$ \\
\hline $\begin{array}{l}\text { Berger et al., } \\
\text { Switzerland [9] }\end{array}$ & $\begin{array}{l}\text { Randomized } \\
\text { controlled trials } \\
\text { (clinical trials) } \\
(n=20)\end{array}$ & $\begin{array}{l}\text { To determine the effects of } \\
\text { trace element } \\
\text { supplementation after burn } \\
\text { injury }\end{array}$ & $\begin{array}{l}\text { a) } 40.4 \mu \mathrm{mol} \text { of copper } \\
\text { b) } 406 \mu \mathrm{mol} \text { of zinc } \\
\text { c) } 2.9 \mu \mathrm{mol} \text { of selenium }\end{array}$ & Greater than 30 \% & 21 to 60 years & $\begin{array}{l}\text { - Decrease broncho- } \\
\text { pneumonial } \\
\text { infections } \\
\text { - Decrease hospital } \\
\text { stay }\end{array}$ & $\begin{array}{l}\text { - A better understanding of the } \\
\text { effects of trace elements on } \\
\text { neutrophil function and the } \\
\text { acute phase response should } \\
\text { be investigated }\end{array}$ \\
\hline $\begin{array}{l}\text { Al-Kaisy et al., } \\
\text { Iraq [8] }\end{array}$ & $\begin{array}{l}\text { Randomized } \\
\text { controlled trials } \\
\text { (clinical trials) } \\
(n=58)\end{array}$ & $\begin{array}{l}\text { To determine the effect of } \\
\text { zinc on recovery rate of burn } \\
\text { patients }\end{array}$ & a) $15 \mathrm{mg}$ of zinc & 15 to $70 \%$ & 6 to 67 years & $\begin{array}{l}\text { - Increase in } \\
\text { antioxidant status } \\
\text { as evidence by } \\
\text { increase in GSH } \\
\text { concentration } \\
\text { - Decrease healing } \\
\text { time }\end{array}$ & - None stated \\
\hline $\begin{array}{l}\text { Sahib et al., } \\
\text { Iraq [7] }\end{array}$ & $\begin{array}{l}\text { Randomized } \\
\text { controlled trials } \\
\text { (clinical trials) } \\
(n=180)\end{array}$ & $\begin{array}{l}\text { To know the effects of } \\
\text { various antioxidants on the } \\
\text { recovery of burn patients }\end{array}$ & $\begin{array}{l}\text { a) } 400 \mathrm{mg} \text { of vitamin E and } \\
500 \mathrm{mg} \text { of vitamin C/day } \\
\text { b) } 75 \mathrm{mg} \text { of zinc sulfate/day } \\
\text { c) } 100 \mathrm{mg} \text { of allopurinol/day } \\
\text { d) } 3 \mathrm{mg} \text { of melatonin/day } \\
\text { e) } 500 \mathrm{mg} \text { of } \mathrm{N} \text { - } \\
\text { acetylcysteine/day }\end{array}$ & 15 to $40 \%$ & Not stated & $\begin{array}{l}\text { - Reduced incidence } \\
\text { of infection } \\
\text { - Reduced wound } \\
\text { healing time and } \\
\text { decrease in } \\
\text { mortality rate }\end{array}$ & - None stated \\
\hline
\end{tabular}


Table 1 Summary of the main findings of the research (Continued)

\begin{tabular}{|c|c|c|c|c|c|c|c|}
\hline $\begin{array}{l}\text { Al-Jawad et al., } \\
\text { Iraq [2] }\end{array}$ & $\begin{array}{l}\text { Randomized } \\
\text { controlled trials } \\
\text { (clinical trials) } \\
(n=60)\end{array}$ & $\begin{array}{l}\text { To explore the variable } \\
\text { effects of } \mathrm{N} \text {-acetylcysteine on } \\
\text { wound healing in burn } \\
\text { patients }\end{array}$ & $\begin{array}{l}\mathrm{N} \text {-acetylcysteine } \\
(500 \mathrm{mg} / \text { day })\end{array}$ & 15 to $40 \%$ & 20 to 40 years & $\begin{array}{l}\text { - Decrease time of } \\
\text { hospital stay } \\
\text { - Decreased healing } \\
\text { time }\end{array}$ & - None stated \\
\hline $\begin{array}{l}\text { Calds-Courtis et } \\
\text { al., } \\
\text { Canada [14] }\end{array}$ & $\begin{array}{l}\text { Prospective cross- } \\
\text { sectional } \\
(n=23)\end{array}$ & $\begin{array}{l}\text { To know the effect of } \\
\text { vitamins } C \text { and } E \text { and zinc on } \\
\text { oxidative stress on burn } \\
\text { patients }\end{array}$ & $\begin{array}{l}\text { a) Ascorbic acid ( } 1000 \text { mg/ } \\
\text { day) } \\
\text { b) Zinc ( } 50 \text { mg/day) }\end{array}$ & 10 to $93 \%$ & 17 to 80 years & $\begin{array}{l}\text { - Zinc concentration } \\
\text { returned to normal } \\
\text { values after } \\
3 \text { weeks } \\
\text { - Zinc } \\
\text { supplementation } \\
\text { did not have } \\
\text { adverse effect on } \\
\text { serum copper } \\
\text { concentration } \\
\text { - Supplementation } \\
\text { did not lead to } \\
\text { gastrointestinal } \\
\text { side effects }\end{array}$ & - None stated \\
\hline $\begin{array}{l}\text { Barbosa et al., } \\
\text { Brazil [15] }\end{array}$ & $\begin{array}{l}\text { Randomized } \\
\text { controlled trials } \\
\text { (clinical trials) } \\
(n=32)\end{array}$ & $\begin{array}{l}\text { To know the duration of zinc } \\
\text { supplementation and the } \\
\text { effects it has on } \\
\text { gastrointestinal side effects }\end{array}$ & $\begin{array}{l}\text { a) Vitamin C (600 to } \\
2700 \mathrm{mg} \text { ) } \\
\text { b) Vitamin E ( } 270 \text { to } \\
1080 \mathrm{mg} \text { ) } \\
\text { c) Zinc ( } 6 \text { to } 22 \mathrm{mg} \text { ) }\end{array}$ & Greater than $10 \%$ & 2 to 15 years & $\begin{array}{l}\text { - Decrease in } \\
\text { wound healing } \\
\text { time }\end{array}$ & $\begin{array}{l}\text { - Dose response studies should } \\
\text { be done }\end{array}$ \\
\hline $\begin{array}{l}\text { Rock et al., } \\
\text { USA [16] }\end{array}$ & $\begin{array}{l}\text { Prospective } \\
\text { randomized trials } \\
(n=27)\end{array}$ & $\begin{array}{l}\text { To know the effect of the } \\
\text { intake of carotenoids }\end{array}$ & a) Beta carotene (30 mg/day) & Greater than $20 \%$ & 18 to 65 years & $\begin{array}{l}\text { - Increase in plasma } \\
\text { concentration of } \\
\text { beta carotene }\end{array}$ & $\begin{array}{l}\text { - A study to know the ability of } \\
\text { antioxidant micronutrients to } \\
\text { influence risk of secondary } \\
\text { tissue injury and disease } \\
\text { should be explored }\end{array}$ \\
\hline Zhang et al. [10] & $\begin{array}{l}\text { Randomized } \\
\text { controlled trials } \\
(n=35)\end{array}$ & $\begin{array}{l}\text { To know the effect of vitamin } \\
\text { E on lipid peroxidates }\end{array}$ & Vitamin E (100 mg/day) & $\begin{array}{l}\text { Severe burns: } \\
\text { greater than } 10 \%\end{array}$ & 14 to 62 years & $\begin{array}{l}\text { - Concentrations of } \\
\text { vitamin E } \\
\text { increased while } \\
\text { lipid peroxides } \\
\text { decreased }\end{array}$ & $\begin{array}{l}\text { - Antioxidant therapy in burn } \\
\text { patients should be explored }\end{array}$ \\
\hline
\end{tabular}

TBSA total body surface area; GSH glutathione 


\section{Study population, setting, and country}

The population of the various studies were similar. The subjects were healthy males and females and children and adults mostly between the age of 6 and 60 years. The exclusion criteria were mainly patients who suffered from other chronic diseases such as renal complications in addition to the burn injury. The percent of total body surface area (TBSA) burned of the patients in all these studies ranged from 10 to $93 \%$.

Most of the studies reviewed in this paper were done in Switzerland [4-6]. There were studies in Iraq [7, 8] and there was a study each in USA, Canada, and Brazil. There was no study done in Africa.

\section{Antioxidant micronutrients considered in the study}

The antioxidant micronutrients considered are vitamins $\mathrm{A}, \mathrm{C}$, and $\mathrm{E}$, copper, zinc, and selenium. In one study, the efficacy of various antioxidants was compared among various groups with respect to the \% TBSA burned [7].

Apart from the micronutrients that were used, $\mathrm{N}$-acetylcysteine was the most efficient antioxidant used [2,7].

\section{Main findings}

One remarkable measure of the rate of recovery is the reduced wound healing time as reported by most of the studies $[2,5,7]$. Apart from that, there was a decrease in mortality rate that was evidenced by shortening in hospitalization period and reduced incidence of infection $[2,7]$. In addition, decreases in protein catabolism as well as increases in the concentration of trace elements in serum and skin tissues of the patients after the clinical interventions were also discovered [5].

The outcome from the studies as reported by Berger et al. revealed that the administration of trace elements caused a reduction in nosocomial infections such as broncho-pneumonial infections [4, 9]. It was also reported that the micronutrient levels were low at the initial stages of the burn injury. However, there was an increase in serum concentration of antioxidant nutrients within a few days of administration of the antioxidant minerals [4-9] as well as a decrease in serum lipid peroxides [10].

It should also be noted that $5.58 \mu \mathrm{g} / \mathrm{ml}$ was the average vitamin $E$ level circulating at the initial stages of the burn injury, but after 20 days of administration of vitamin E, the level increased to $8.58 \mu \mathrm{g} / \mathrm{ml} \mathrm{[10].} \mathrm{Serum}$ glutathione (GSH) also increased from $2.2 \mathrm{Mu} / \mathrm{mg}$ protein at the initial stages of burns to $16.8 \mathrm{Mu} / \mathrm{mg}$ protein at day 20. This gives an indication of increase in circulating antioxidants after administration of nutrients.

Moreover, a normalized antioxidant status of patients who received the interventions as evidenced by an increase in GSH concentration [2] in the plasma is a good indication of the positive effect of trace element supplementation on burn patients.

The efficacy of antioxidant micronutrients on the recovery rate of burn patients can hence be ascertained with these positive results and indications.

\section{Research gaps}

According to the results, it is important to note that no published work exists for Africa and this creates a research gap. African women and children are more vulnerable to or are at high risks to burn injury, as a result of their lifestyle and their role in preparing the household meals. In Africa, poverty, illiteracy, and urban migration lead to overcrowding and unemployment. In most cases, mothers hunt for jobs and leave their children unattended, exposing these children to the risk of burn injury. In addition, the use of open flames in cooking is a serious risk factor.

It was also evident from the review that there was little attention on children below 6 years of age (only one study included them), and this gives rise to a research bias. There are several children in Africa who are malnourished; hence, a study to know how they are affected by burn injury will be a worthwhile study. It has become important because, in the various developmental milestones, children need nutrients for growth and development; hence, a study to know what happens to them under burn injury will be an interesting one.

All the studies reviewed gave promising results about the safety and efficacy of antioxidant nutrients on burn patients, but they all had one thing in common: small sample size. It has therefore been recommended that large multicenter trials are required to confirm these encouraging data as well as explore its applicability in burns and critical illness [5, 6]. Another study also recommended that, since trace elements have a dose response effect, there should be a study to find the appropriate doses and duration of treatment in burns for utmost recovery [5].

Currently, only 11 papers in this field have been published in 23 years. They varied in the parameters reported: immune cell functions, antioxidant levels, and outcome of the wound healing process. In general, these reports indicate that antioxidant supplements benefit burn patients, but more studies with careful clinical designs are required to find out the variety of the antioxidants, the dose, the timing, and the duration of the antioxidants to be used and the specially targeted parameters. These specific trials can include "the pulmonary function in burn patients with inhalation injury." Extensive non-human studies have been reported, but it is also important in translating their results into clinical practice.

Neutrophils provide the first line of defense against infection by its phagocytic action on microorganisms and 
debris. Though some studies reported the potential role of trace elements in increasing the level of phagocytes, it has been recommended that a better understanding of the effects of trace elements on neutrophil function and the acute phase response should be investigated.

The role of antioxidant micronutrients cannot be overemphasized in these studies; hence, a study on antioxidant therapy in burn patients should be seriously considered [10].

\section{Discussion}

The various results obtained from the studies indicate that the effect of multiple antioxidants on the rate of recovery of burn patients is outstanding. In the study by Berger et al., it is noted that the nutrients used as an intervention had a positive effect on wound healing, infection rate, protein turnover, and protein catabolism [4]. Studies by Al-Jawad et al. and Al-Kaisy et al., where single antioxidant nutrients were used, showed that there was an improvement in only one outcome variable $[2,8]$.

The synergistic role of the various micronutrients in the recovery outcomes was evident; hence, the role of individual micronutrients in the recovery outcomes can be challenging to know. Hence, a study to find out the role of each of the micronutrients will be beneficial, as Berger et al. stated that selenium is a major nutrient that can be investigated alone because of the role it plays in oxidative stress as seen in animal models [4].

The effect of micronutrients and the role they play in immunity cannot be overemphasized. Some studies that measure infection rate have established that trace elements may have an effect on the neutrophil level in an individual. It is reported by Berger et al. [4, 9] that trace element supplementation reduced infection rates. Ross et al. report that selenium is likely to play a role in immune function and hence is a major research area [11].

Zimmerman et al. and Winichagoon et al. reported that supplementation of micronutrients such as zinc in young people can help in their growth and development and cognitive function [12, 13]. Zinc plays crucial roles in oxidative stress, bone formation, taste acuity, and the stabilization of membranes and also in the formation of connective tissues [11]. A burn child is likely to be deficient in zinc and becomes vulnerable to all kinds of infection due to prolonged deficiency after burn injury.

Most of the antioxidant micronutrients were given in doses higher than their recommended daily allowances; it was therefore considered as a therapeutic dose. As to whether the required quantities of the micronutrients can be obtained in the diets of the patient remains unknown. Interventional studies dominated the results of this study. There was no study done on a cross-sectional prospective basis; hence, designing a study in that manner can give detailed information about the situation in developing countries.

\section{Conclusions}

Based on the forgoing review, the use of antioxidant nutrients such as vitamins A, C, and E, copper, zinc, and selenium confers health benefits to burn patients. This ranged from a reduction of infection rates, reduction in wound healing time, and shortening of the length of stay in hospitals. It is evident from this review that there are several gaps with respect to nutritional management. There is also a need for more work to be done in the African population where the inhabitants are more prone to burn injury. This paper therefore urges scientists to take an active role in burn research to help the vulnerable people in society.

\section{Competing interests}

The authors declare that they have no competing interests.

\section{Authors' contributions}

MA, PA, PB, and IO conceived the idea. PA and MA searched for the papers and wrote the manuscript. MA, PA, PB, and IO critically edited the manuscript. All authors read and approved the final manuscript.

\section{Author details}

${ }^{1}$ Department of Biochemistry, College of Science, Kwame Nkrumah University of Science and Technology, Kumasi, Ghana. ${ }^{2}$ Department of Surgery, Reconstructive Plastic Surgery \& Burns Unit, Komfo Anokye Teaching Hospital, School of Medical Sciences, College of Health Sciences, Kwame Nkrumah University of Science and Technology, Kumasi, Ghana.

Received: 20 August 2015 Accepted: 27 April 2016

Published online: 03 August 2016

\section{References}

1. Organization, W.H. Burns. Available in: http://www.who.int/violence_injury_ prevention/other_injury/burns/en/. Accessed 5 Jan 2015.

2. Faruk $\mathrm{H}, \mathrm{Al}$-Jawad ASS, Ahmed HI, Al-Kaisy AA. Effect of $\mathrm{N}$-acetylcysteine on wound healing in burned patients. Mustansiriya Med J. 2011;10(1):28-31.

3. Arina P. Nutritional management of the burn patient. S Afr J Clin Nutr. 2009;22(1):9-15

4. Berger MM, Heyland P, Chiolero RL, Revelly JP, Day A, Raffoul W, et al. Reduction of nosocomial pneumonia after major burns by trace element supplementation: aggregation of two randomised trials. Crit Care. 2006;10(6):R153.

5. Berger MM, Chiolero RL, Taylor W, Raffoul W, Cayeux MC, Benathan M. Trace element supplementation after major burns increases burned skin trace element concentrations and modulates local protein metabolism but not whole-body substrate metabolism. Am J Clin Nutr. 2007;85(1):1301-6.

6. Berger MM, Raffoul W, Benathan M, Chiolero RL, Reeves C, Revelly JP. Trace element supplementation after major burns modulates antioxidant status and clinical course by way of increased tissue trace element concentrations1. Am J Clin Nutr. 2007;85:1293-300.

7. Sahib AS, AlKaisy AA. Effect of anti-oxidants, on the incidence of wound infection in burn patients. Ann Burns Fire Disasters. 2010;23(4):199-205.

8. Al-Kaisy AA, Al-Jawad ASS, Al-Bait HAHK. Effect of zinc supplement in the prognosis of burn patients in Iraq. Ann Burns Fire Disasters. 2006;29(3):115-23.

9. Berger MM, Shenkin A, Wardle C, Wiesner L, Schindler C, Chiolero RL. Trace element supplementation modulates pulmonary infection rates after major burns: a double-blind, placebo-controlled trial 1-3. Am J Clin Nutr. 1998;68:365-71.

10. Zhong M, Wang Q, Gao L, Jin H, Wang Z. Comparative observation of the changes in serum lipid peroxides influenced by the supplementation of vitamin E in burn patients and healthy control. Bums. 1992;18(1):19-21. 
11. Catherine AR, Robert BC. Cousins J, Tucker KL, Ziegler TR, Modern nutrition in health and disease. Eleventh edition ed. 2013: Lippincott Williams \& Wilkins, a Wolters Kluwer business.

12. Winichagoon $P$, Chavasit $V$, Pongcharoen $T$, Gowachirapant S, Boonpraderm A, Mangr MS, et al. A multimicronutrient-fortified seasoning powder enhances the hemoglobin, zinc, and iodine status of primary school children in north east Thailand: a randomized controlled trial of efficacy. J Nutr. 2006;136:1617-23.

13. Zimmermann MB, Zeder C, Chaouki N, Saad A, Torrsanin T, Hurrell RF. Dual fortification of salt with iodine and microencapsulated iron: a randomized, double-blind, controlled trial in Moroccan schoolchildren. Am J Clin Nutr. 2003;77(2):425-32.

14. Caldis-Coutris N, Gawaziuk JP, Logsetty S. Zinc Supplementation in burn patients. J Burn Care Res. 2012;33(5):678-82.

15. Barbosa E, Faintuch J, Machado Moreira EA, Gonçalves da Silva VR, Lopes Pereima MJ, Martins Fagundes RL, et al. Supplementation of vitamin E, vitamin C, and zinc attenuates oxidative stress in burned children: a randomized, double-blind, placebo-controlled pilot study. J Burn Care Res. 2009;30(5):859-66.

16. Rock CL, Dechert RE, Khilnani R, Parker RS, Rodriguez JL. Carotenoids and antioxidant vitamins in patients after burn injury. J Burn Care Rehabil. 1997:18(3):269-78

\section{Submit your next manuscript to BioMed Central} and we will help you at every step:

- We accept pre-submission inquiries

- Our selector tool helps you to find the most relevant journal

- We provide round the clock customer support

- Convenient online submission

- Thorough peer review

- Inclusion in PubMed and all major indexing services

- Maximum visibility for your research

Submit your manuscript at www.biomedcentral.com/submit 